\title{
Tourism Competitiveness and Sustainability Indicators in the Context of Surf Tourism: The Case of Cape Town
}

\author{
Roberto Martín-González $^{1}{ }^{\mathbb{D}}$, Kamilla Swart ${ }^{2,3, *}$ and Ana-María Luque-Gil ${ }^{1}$ \\ 1 Faculty of Tourism, University of Málaga, Campus de Teatinos s/n, 29071 Málaga, Spain; \\ robertomartingonzalez@alu.uma.es (R.M.-G.); geoana@uma.es (A.-M.L.-G.) \\ 2 Division of Engineering Management and Decision Sciences, College of Science and Engineering, \\ Hamad Bin Khalifa University, Education City, Qatar Foundation, Doha 24404, Qatar \\ 3 School of Tourism and Hospitality, University of Johannesburg, Johannesburg 2092, South Africa \\ * Correspondence: kswartarries@hbku.edu.qa; Tel.: +974-4454-0942
}

Citation: Martín-González, R.; Swart, K.; Luque-Gil, A.-M. Tourism Competitiveness and Sustainability Indicators in the Context of Surf Tourism: The Case of Cape Town. Sustainability 2021, 13, 7238 https://doi.org/10.3390/su13137238

Academic Editors: Patrick Bouchet and Claude Sobry

Received: 18 May 2021

Accepted: 23 June 2021

Published: 28 June 2021

Publisher's Note: MDPI stays neutral with regard to jurisdictional claims in published maps and institutional affiliations.

Copyright: (c) 2021 by the authors. Licensee MDPI, Basel, Switzerland. This article is an open access article distributed under the terms and conditions of the Creative Commons Attribution (CC BY) license (https:// creativecommons.org/licenses/by/ $4.0 /)$.

\begin{abstract}
Sport tourism has experienced considerable growth in the last decades, either from the sport events perspective or considering an active sport tourism approach. Therefore, some emergent market niches like surf tourism have been developed in numerous coastal destinations to attract sustainability-sensitive tourists due to the ongoing environmental challenges and the socio-economic crisis. Cape Town is positioned in a prominent place in terms of competitiveness, with a considerable variety of beaches and surf spots facing multiple issues. The aim of this study is to try to identify the most competitive beaches and subdistricts in terms of sustainability and to suggest criteria for surf-tourism-related indicators to obtain an overview about this space, using weighting indicators, and applying geography and political economy lenses. The results reveal that Strand, Table View, and Surfers' Corner are the most competitive beaches. Additionally, beaches located in some underprivileged areas such as Mitchells Plain and Khayelitsha are potentially interesting from a socioeconomic development point of view, although they show a lack of accommodation infrastructures. These results seem to indicate that those areas should be closely monitored, and destination managers should focus their attention and finance there to obtain a more sustainable surf tourism development.
\end{abstract}

Keywords: sport tourism; surf tourism; tourism competitiveness indicators; sustainable tourism

\section{Introduction}

The growth of sport tourism from the end of the last millennium is well known [1,2] although its sustainability has also been put into question for this reason [3]. The recent COVID-19 crisis has exacerbated the issues related to tourism activities worldwide, highlighting the weaknesses of tourism markets such as sport event tourism [4] or the meetings, incentives, conventions, and exhibitions sector [5]. At the same time, it has enhanced the importance of sports and outdoor activities for maintaining physical and mental health $[6,7]$, and a desire for increasing participation in such activities when the pandemic is announced as concluded has been reported [8]. Amongst those outdoor activities, surfing [9] and surf tourism have experienced a continuous growth [10], with countries historically reluctant to its practice, such as China, getting involved in it [11]. In this context, many coastal destinations have developed surf tourism as a way to develop their socio-economic potential [12-14], with others being interested by the possibility of attracting sustainability-sensitive tourists, as surfers seem to develop pro-environmental behaviors $[15,16]$. This is the case of Cape Town in South Africa $[17,18]$. Nevertheless, the sustainability of surf tourism is controversial $[19,20]$. Consequently, some tools have been proposed from the academy [21-23], although they have only been applied in Thailand and focus on sustainable planning [24], while in Cape Town, socio-economic indicators were implemented in the context of the health crisis created by the spread of COVID-19, but with a lack of environmental indicators [25]. 
The main objective of this article is to try to identify the most competitive beaches and subdistricts in terms of sustainability, as well as to suggest criteria for surf-tourismrelated indicators to assess tourism potential, based on sustainable tourism destination competitiveness, using weighting indicators and applying geography and political economy to Cape Town beaches. It also seeks to extend the limited socio-economic indicators implemented in the previous study, adding environmental indicators and readjusting the weights.

The obtained results seem to indicate that there are three main areas with three different characteristics in terms of sustainability. First, the Western area seems to have an economic competitive advantage, since most of the surf companies and accommodation units are concentrated in that part of Cape Town. Second, the Southern coast has reached the highest score in terms of environmental sustainability. This area houses a variety of surfing spots and includes Seal Island and most Shark Spotters posts, which indicates that there is a wide range of wildlife. Third, the area that includes Mitchells Plain and Khayelitsha obtained the greatest score for the social indicator, as they experienced a lower impact of the COVID-19 first wave. Additionally, the high number of social infrastructures seems to have importance in that result as well. On the other hand, it has also revealed the weaknesses of each area, showing that unprivileged areas need more tourism infrastructures (e.g., accommodation units) to gain an advantage in surf tourism development. The study starts with the theoretical framework adopted (political economy, tourism system theory, and tourism competitiveness), and then continues with a literature review of sport tourism and surf tourism. Section 2 concludes with a review about the linkages between tourism potential, competitiveness, and sustainability indicators. Then, the material and methods are outlined in Section 3, starting with the study area. It continues with the methodology and sources, and concludes with the surf tourism sustainable indicators. Thereafter, the results are presented in Section 4, differentiating between beaches and subdistricts. Finally, the article ends with a short discussion and conclusion of the results.

\section{Theoretical Framework and Literature Review}

Broadly, political economy is concerned with socio-economic actors and the relations that are established during the production of commodities for the market [26]. This theory helps with the identification of the basic elements to be studied in the context of a capitalist system (consumers, producers, regulatory bodies, and products) [18,25], as illustrated in Figure 1.

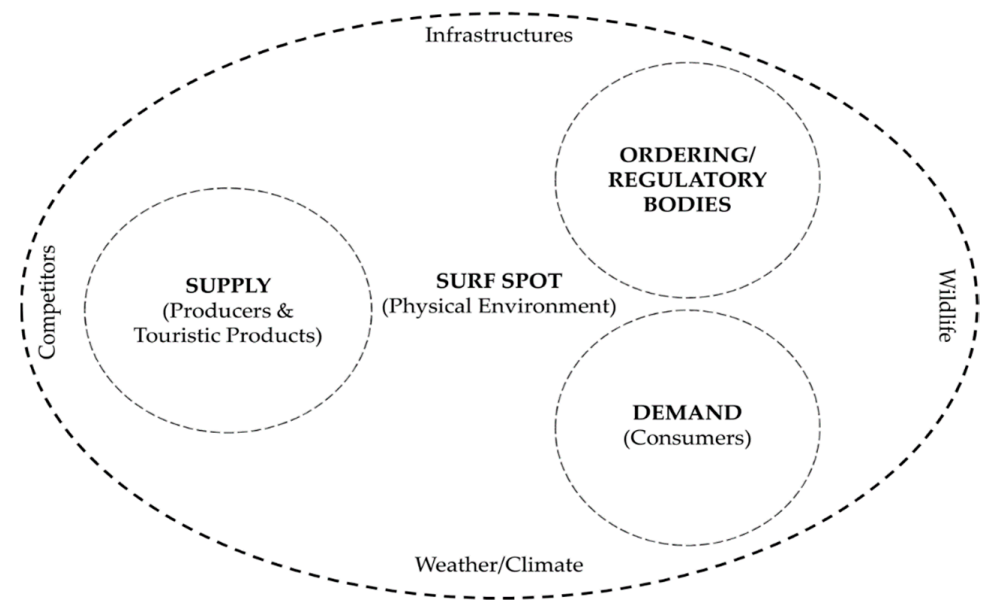

Figure 1. Surf tourism system.

Additionally, tourism can be viewed as a system, which includes some key elements such as consumers, producers, tourist products (e.g., cultural resources, accommodation, ancillary services, etc.), and the ordering/regulatory bodies that have a key role in planning and management for tourism development [27]. In the context of surf tourism, it is possible 
to affirm that the surf spot (and the area around it) is the main resource, and most of the time, it is a natural area whose boundaries encompass elements that go beyond the beach [28]. Thus, it is possible to add a series of elements, such as the infrastructure, the competitors, the weather/climate, and the wildlife [18]. On the other hand, competitiveness is a key factor for the successful development of tourism destinations [29,30], as tourism potential is a decisive element for effective planning and management [31].

This section first explores the current state of the art of sport tourism, as well as looking at academic perspectives on surf tourism. Then, the concept of sustainable indicators to measure and assess the tourism potential and, therefore, the competitiveness of surf destinations is also reviewed.

\subsection{Sport Tourism}

The act of travelling to practice or watch sporting activities is not new, with the ancient Olympic Games being commonly accepted as the beginning of sport tourism [32,33]. In modern times, specially from 1960, tourism and sports have experienced a considerable evolution and growth, given the economic and social changes experienced worldwide, which include the democratization of both, that have increased the profile of sports and tourism participants (e.g., for people with disabilities) [33]. Moreover, since then, society has experienced a shift in its leisure habits, with an increasing interest in health and fitness, and active participation in sports during the holidays and leisure time [34], which is a common trend of postmodern societies [35]. Additionally, sport and tourism have played an important role in the response to the COVID-19 pandemic, and active outdoor activities like cycling have experienced considerable growth, highlighting the importance of sport tourism [36].

In another vein, there is certain agreement in academia about the origin of its conceptualization, which dates back to the mid-1960s in the United Kingdom [37]. Thenceforth, a wide variety of potential meanings has appeared [2,38,39], as the concept of sport tourism, which is socially constructed, is complex and difficult to define [40,41], causing intense debates about its terminology, categorization, and limits [2].

Earlier definitions tried to delimitate the phenomenon of sport tourism, linking the practice of sporting activities with holidays, such as the one proposed by Hall (1992), cited in Higham and Hinch [41], that excluded 'commercial' reasons for traveling. Later, Standeven and De Knop [32] included such reason in their definition, differentiating between active or passive involvement in sports. At the same time, Gibson [42] added the visit of sport museums and other types of nostalgic attractions as a different typology of motivation, differentiating between active events and nostalgia sport tourists, creating one of the hegemonic definitions and categorizations in the field [43]. On the other hand, Weed and Bull [33] indicated that more than a trip purpose, sport tourism should be considered a behavior, which could be experienced in a vicarious manner [44].

The development of new conceptualizations, categories, and improvements of sport and sport tourism theories, such as lifestyle sports [45], adventure sports [46], nostalgia/heritage categories [47], and the serious leisure perspective (amongst others), have enriched academic research in the field, offering new avenues for sport innovation and the development of new sport tourism experiences [34]. Considering these advancements, Weed and Bull proposed a different (and broader) definition, changing slightly the terminology by adding an ' $\mathrm{s}$ ' to 'sport' (sports tourism), in order to accommodate the increasing number of existing conceptualizations and theories, in line with the view of tourism and sports (and the intersection of both) as complex phenomena [2].

Nonetheless, the later conceptualization, and the change of terminology, might have created even more confusion, rather than clarifying the field of study [38]. As a result of this potential confusion, Hinch, Higham, and Sant [43] suggested researchers use a definition according to the context of their studies and in line with the supporting literature. In content analysis regarding the sport tourism definition performed by Van Rheenen, Cernaianu, and Sobry [38], more than 30 different conceptualizations of sport tourism were 
found from more than 80 selected pieces of literature published in the Journal of Sport \& Tourism. They could identify five distinct dimensions: (1) time, (2) space, (3) type of sport that motivated the travel, (4) participant experience, and (5) reference to the development of an economic sector or niche market.

Following Hinch et al.'s [43] suggestion, this study will make use of the sport tourism definition provided by Gibson [42]. Amongst the sport tourism niche markets that have been developed during the 1990s (e.g., cycling, climbing, etc.) surf tourism can be considered as one of the more promising in terms of sustainability, but with fast growth in both participants and interest from academia, being an important research branch of sport tourism studies [48]. The selected definition seems to cover the motivations, behaviors, and the existent surf-tourism-related products (active participation, events, and surf museums), although it appears important to note that active surf tourism is more popular than surf events (and/or nostalgia/heritage surfing-related products), since it is not an activity that has the potential to congregate spectators around the area of play, which is often difficult to reach ([49], p. 32). Nonetheless, there is an increasing interest from governments, global sports organizations, and multinational surf companies, for developing commercial surfing-related products in developing nations, resulting in ethical issues and potential inequities [34].

\subsection{Surf Tourism}

The practice of surfing has its roots in Pacific cultures in the Polynesian islands and South America [50]. The birth of modern surfing as a lifestyle can be set at the beginning of the last century, starting from Hawaii, United States of America (USA), with the objective of attracting tourists and investments to the islands [51]. It was then exported to and commodified in the rest of the Anglo-Saxon countries (mainly Commonwealth countries), such as the United Kingdom, Australia, and South Africa, as noted by Nendel [52]. Surfing then expanded to the rest of the non-Anglo-Saxon countries with surfable coasts and shores from the 1960s, with a rapid spread over Europe (especially from Biarritz, France) from the 1970s [53]. Nowadays, it is an activity practiced worldwide with a multibillion USD industry behind it, which includes travel to destinations where surfing is possible, with a corpus of academic literature supporting it as well [48].

The role played by the (big) surf corporations - especially those originally from Australia, such as Rip Curl, Quiksilver and Billabong-in creating an ideal image of surfing and of surfers as adventurers with a particular lifestyle (hedonism, freedom, love, etc.) that must be considered as a sustainable activity, has already been analyzed critically, both in books (e.g., [54]) and articles (e.g., [55]). Apart from these studies that are focused on the most common type of surfing-the type practiced with a shortboard-surfing-related sports (SRSs) involve many others. Surfing is basically a type of nature sport which can be practiced in a variety (and mix) of surfaces and dynamic forces that create the conditions to practice them [56], including water, air, snow, and sand. Focused on water-based surfaces, SRSs can be divided based on the forces that create the conditions: wave-based (surfing, bodyboarding, stand-up paddle surf (SUP)), wind-based (kitesurfing and windsurfing), and self-propelled (wakeboarding, foil-surfing, and SUP). SRSs have experienced a maintained growth in the form of participants, surf destinations, media attention, government interest, and academic research from different fields, such as nature sciences (e.g., oceanography), sports, tourism, and cultural studies from the beginning of the millennium [57]. This increase in interest has been boosted, amongst other things, by technological advances like weather forecast tools, being a paradigmatic case of individual sports in the context of a globalized and postmodern society that seeks adventure and escape to nature, where knowledge, aimed by information technologies [58], occupies a central role. In this context, South African surf destinations, and Cape Town in particular as a global city, is in a privileged situation with a varied offering of surf spots that form a complex touristic system [18] that is not only potentially competitive in the tourism market of surf destinations worldwide, but also in terms of sustainability, due to the place-protecting behavior 
showed by surfers [15]. This fact has kickstarted many surf tourism development projects worldwide, such as those in Oceania [59] and Africa [14]. Nonetheless, the sustainability of surf tourism still remains controversial, as surfers are highly mobile [20], the impact of the coastal development boosted by surfers can be harmful [60], and the surfing industry in general has showed very little interest for sustainability issues [54]. In the context of South Africa, surfing has distinctive characteristics that differ from that type of lifestyle, being, historically, an activity practiced by the white (and male) community shaped by the apartheid policies and rules adopted by South Africa until 1992 [61].

\subsection{Tourism Potential, Competitiviness and Sustainability Indicators}

In general, indicators can be defined as 'measures of the existence or severity of current issues, signals of upcoming situations or problems, measures of risk and potential need for action, and means to identify and measure the results of our actions' [62] (p.8). In the context of tourism, these indicators should represent 'information sets which are formally selected to be used on a regular basis to measure changes that are of importance for tourism development and management' [62] (p. 8) that 'may reduce the chances of unknowingly taking poor decisions' [63] (p. 9). As remarked by Garret and Latawiec [64] (p. 12) they are important for both policy development and scientific inquiry in the context of complex systems, since they provide qualitative and quantitative information about the trajectory and condition of a system in particular contexts. In tourism, these products, resources, and services are the main elements contained in the markets which can be included in the assessment of the tourism potential of a territory or destination [31]. The tourism potential can be defined as 'the pool, array and collection of natural, cultural and manmade tourism resources possessed by a community, state and/or country that can be transformed and developed into visitor-ready attractions or finished products and services packaged to provide touristic experiences' [65] (p. 574). The creation of an inventory of these elements is the first step to follow to assess the tourism potential. Then, the tourism potential can be calculated based on the level of importance of certain resources, establishing their weighting coefficients to obtain a total tourism potential value. On the other hand, the multicriteria analysis also uses the weighting method, which enriches the analysis, considering different alternatives [31]. There are some examples of studies that have employed this method [66-68] as well as the multicriteria analysis [31,69], which implies a more complex and varied system with different alternatives.

In the case of surf tourism, Martin developed what he called a 'Surf Resource Sustainability Index' [21] that has been refined by Martin and Assenov [22,24,70], and clarified in terms of the calculation of weights by Martin and Ritchie [23]. Nevertheless, there is a lack of application in other spaces apart from Asian countries, such as the study of Cape Town and the COVID-19 crisis [25].

\section{Materials and Methods}

\subsection{Study Area}

Cape Town is the capital of the Western Cape Province (WC), as well as the legislative capital of South Africa. It is the second most populated city in the country, with an extension of $2455 \mathrm{~km}^{2}$ and a population of over 4 million inhabitants [71]. From a socio-economic point of view, Cape Town is still a city highly affected by both apartheid and the heritage of colonialism. As noted by Miraftab [72], the socio-spatial relations in Cape Town have been shaped by both colonialism and apartheid laws that have 'privileged whites' access to Cape Town resources. Moreover, the land policies applied during the post-apartheid era, such as housing delivery and informal settlement regularizations, have also conditioned Cape Town's current apartheid geography, which includes underprivileged areas such as Khayelitsha, with a majority-African population, as well as Coloured ones such as Mitchells Plain [73]. These neighborhoods form part of the so-called Cape Flats, which are far from the touristic areas and show high rates of crime and health issues [74], while most of the 
white population is concentrated on the Atlantic Coast and closer to the city center, where most of the jobs and resources are located [75].

Geographically, it is situated at the coordinates $33^{\circ} 55^{\prime} 33^{\prime \prime}$ southern latitude and $18^{\circ} 25^{\prime} 23^{\prime \prime}$ eastern longitude of the southern hemisphere. The municipality, in general, has a mild-Mediterranean climate, with warm and dry summers and wet and soft winters, and different micro-climates in the same space where the western face of Table Mountain receives most of the rains. Meanwhile, the Flats (east from Table Mountain) are dryer due to the storms, which hit Cape Town during the winter and come mainly from the north-west [76]. It is situated between two oceans currents, the cold Benguela Current, affecting mainly the Atlantic side, and the Agulhas current that contributes warmer water to False Bay and the South Peninsula [77], offering a wide range of landscapes and biodiversity within the same municipality. It has almost $300 \mathrm{~km}$ of coastline, which houses a rich diversity of wildlife and offers many opportunities for recreation and leisure activities [78].

This geographical position (together with the man-made features) provides Cape Town with the wave and wind resources to become one of the major centers of surfing in South Africa [79]. The Cape Town Municipality website counts more than 70 beaches with infrastructures available for tourists and locals. It also contains, according to the website Wannasurf [80], more than 100 wave-based surf spots.

In fact, Muizenberg (see Figure 2, below) is considered the place where surfing started to spread through the African continent [81]. Recently, surf tourists have been pointed out as a promising market niche to promote sustainable tourism by the local tourism board due to the water crisis suffered by Cape Town beginning in 2016. Additionally, the recent socio-economic crisis arising from the COVID-19 pandemic has put the spotlight on the importance of health issues and public investments in health services and infrastructures, and the lack of a strong element of sustainability in tourism in general, while showing that sports have a high positive impact on public health.

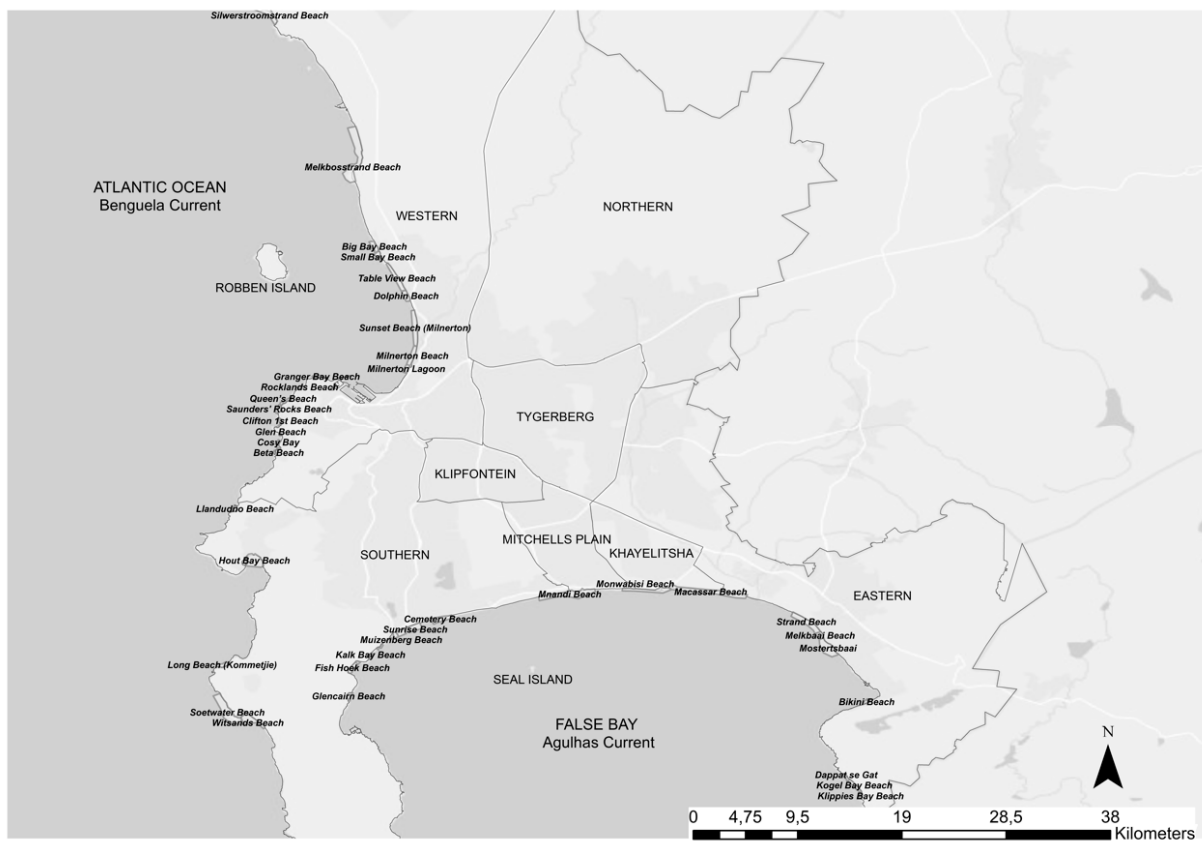

Figure 2. Cape Town surfing beaches and health subdistricts.

Regarding tourism, Cape Town is an internationally recognized destination [82], inter alia, because governments involved in tourism development, from national (ruled by the African National Congress party) to regional and local (ruled by the Democratic Alliance party), have been implementing different urban planning and management programs, under the umbrella of the different policy frameworks that have highlighted tourism as a key for development, especially since the 1990s, once South Africa embraced democracy [83]. 
Unfortunately, inequalities are persistent [84] and the unemployment and poverty rates in Cape Town are high, which according to Miraftab [72] could be a consequence of an urban planning based in business districts, which seems to have failed in the aim of attracting equity and integration to all Cape Town communities, not because of the lack of policy efforts, but because of their implementation.

Following the Cape Town Regional Trends 2019 Report [85], the tourism data before the COVID-19 crisis showed a high dependence on domestic tourism (66.7\%). The main contributors were tourists coming from the same region (Western Cape, with 39.9\%), while Gauteng represented the second most important national market $(31.3 \%)$. On the other hand, Germany (16.2\%), the United Kingdom (11.7\%), and France (8.5\%) were the main international markets. The main motives for visiting Cape Town were holidays/leisure $(86.8 \%)$ and business $(4.1 \%)$, while the main activities reported were (1) outdoor activities (52\%), followed by (2) scenic drives (30\%), and (3) cultural and heritage activities (17\%). Nevertheless, Cape Town is also specialized in different market niches, such as wine tourism, event tourism (musical, sport), sun and beach, shopping, adventure tourism (shark diving), ecotourism (floral and wildlife sightseeing), pro-poor tourism, and so on [86].

In terms of sport tourism, Cape Town may be considered a destination with the potential to be top in the international arena, as it has resources of high quality and remarkable sport events. It counts Table Mountain and its beaches as the main resources, where both residents and tourists can practice activities in nature, such as hiking, mountain biking, swimming, water board sports, kayaking, and so on [86]. These individual sports are growing in terms of both activities and participants all around the world [34]. Three annual major events are scheduled in the city and performed in its roads and mountain chains (mainly around Table Mountain): the Cape Town Cycle Tour [87], the Two Oceans Marathon [88], and the mountain bike race Cape Epic [89]. Regarding surfing-related events, the Big Wave Red Bull Africa (considered as the most important Big Wave event in the world) was held more than ten years ago [90], and The King of The Air (the most recognized kite-surfing event worldwide) has been scheduled several times [18], both sponsored by Red Bull, the energy drink specializing in extreme sports events sponsorship.

Thus, taking into account that surf tourism is an outdoor activity, it seems clear that it has a relative importance in Cape Town. Finally, the celebration of world-class surfing events by Red Bull could also be a sign of the significance of surf tourism in the area.

\subsection{Methodology and Sources}

A quantitative methodology has been applied to this study, using weighting indicators to obtain coefficients that would allow us to draw results and conclusions about the sustainability of the beaches regarding surf tourism activities, as noted above. The software ArcGIS 10.1.7 was used to map the beaches and the features included in the study. Additionally, a qualitative methodology was used to enrich the research, interviewing key informants in the area from the three main realms of the surf tourism system (the supply side, the demand side, and the regulatory bodies), as well as from the academic sphere.

Primary data include informal and unstructured interviews with key actors to understand the surfing reality in Cape Town, which helped in the selection and construction of the indicators. Interviewees were selected using the snowball technique and following the criteria mentioned above. These included two interviews of $1 \mathrm{~h}$ each, acquiring information about surf clubs and the role of surfing culture in South Africa and Cape Town, with a surfer and researcher involved in surfing-related non-governmental organizations specializing in surfing history in South Africa. Additionally, five interviews of $1 \mathrm{~h}$ each took place regarding the geography of tourism and surf tourism in Cape Town, Western Cape, and South Africa, with a renowned South African geographer specializing in tourism. Another five interviews of $1 \mathrm{~h}$ each, regarding the role of active sport tourism and sport tourism events in Cape Town in terms of sustainability, took place with a reputable South African academic in the area of sport tourism. Regulatory bodies were also included, and one interview of $1 \mathrm{~h}$ with a member of the municipal government regarding the role of the 
municipality in surf tourism development in Cape Town was also performed. In the same vein, a key actor involved in the production of surf tourism products was also interviewed, including two interviews of $1 \mathrm{~h}$ each with a South African surfing champion and owner of a surf company in the area.

Secondary data included articles, book chapters, and other pieces of academic literature (115 in total) which were analyzed in a literature review published elsewhere [18]. Another important source was the Cape Town website [91], where data related to the beaches was collected in relation to infrastructures and services. From 78 beaches listed on the municipality portal, 49 were chosen, considering that those selected had to include at least one surf spot marker. After a data refinement of the total number of surf spots' markers (around 400), 119 different surf spots were mapped; however, only those included in the 49 selected beaches (92) were incorporated in the study.

The quality of the water was measured based on the four different rates given (Poor, Sufficient, Good and Excellent) in the annual report 'Know your Coast' [92]. Additionally, the data related to the 2011 South African census was also used to obtain an idea about the crowding of the analyzed areas around the beaches. On the other hand, the software ArcGIS 10.7.1 was used to map the beaches, represent the data, and make the needed spatial calculations related to the indicators (e.g., hospitals, clinics, and police stations near the selected beaches).

Global surf forecast websites focused on wind-based surfing, such as Windguru [93] and Windfinder [94], as well as those ones focused on wave-based surfing, such as Magic Sea Weed [95], Surf forecast [96], Surfline [97], and the local Wavescape [98] were used for the collection of surf spots. Additionally, the surf wiki Wannasurf [80] was used to obtain the data related to the seabed, and also the wave-based surfing spots.

The calculation of the indicators followed the method used in the study of Cerezo and Galacho, which focused on adventure tourism in the rural area of La Sierra de las Nieves, Málaga, Spain [67], and in the study of Martín-González, Swart, and Luque-Gil (2021) [25]. The main problem seems to be assigning the weights of the elements [31], which in the case of the study carried out by Cerezo and Galacho [68], were the following: resources 50\%, accessibility $30 \%$, and facilities $20 \%$. They assigned the hierarchy of each resource based on the attractiveness of the demand ( 1 for international tourism, 5 for local). Here, we will assign weights following a sustainable criterion based on a balanced importance (economic $33 \%$, social 33\%, and environmental 34\%) and keeping the same hierarchy levels based on the attractiveness of the demand, considering at the same time the results obtained in the previous work of Barbieri and Sotomayor [99] regarding surf tourists' behavior and destination preferences, as well as our expertise and previous experience in the field of study as academics, researchers, and active participants in surfing, all of which were also considered in setting the value of the multipliers.

\subsection{Surf Tourism Sustainable Indicators}

Thirty-four indicators (Table 1) have been chosen from a variety of potential indicators recommended by Martin and Assenov [22], taking into account the availability of the data and the expertise of the researchers in the field (Author 1, with more than 10 years of experience as a surfer travelling to Portugal, Spain, Indonesia, and South Africa, also spent two years in Cape Town, from 2014 to 2016, in the Centre of Tourism Research in Africa (CETRA) in the context of an Erasmus Mundus exchange program, surfing regularly in many of the surfing spots under study, interacting with local surfers and surf tourists and doing direct observations; Author 2 has experience as an international expert in the field of sport tourism and is resident of Cape Town; Author 3 is a reputable international expert on sport geography and active sport tourism). These indicators have also been enriched by the information provided by key informants (e.g., the density white pop. indicator was selected based on conversations with the researcher specializing in surf history in South Africa). 
Table 1. Assessment criteria and implications. Source: Adapted from Martín-González et al. (2021) [25].

\begin{tabular}{|c|c|c|c|c|c|}
\hline Environmental Indicators (Ien) & Assessment Criteria & Implications & Hierarchy & Multiplier & Data \\
\hline Variety spot & $\begin{array}{l}\text { Identify and list the number of surf } \\
\text { (wind and/or wave-based) spots } \\
\text { located in a beach. }\end{array}$ & $\begin{array}{l}\text { A greater number of spots implies that a } \\
\text { greater variety of types of surfing can be } \\
\text { practiced, and therefore, the area is more } \\
\text { sensitive from an ecological point of view } \\
\text { since it can attract more people. }\end{array}$ & 1 & $\mu_{1}=2.2500$ & Quantitative \\
\hline Wave and or wind spots & $\begin{array}{l}\text { Discriminate between wave } \\
\text { and/or wind spots. }\end{array}$ & $\begin{array}{l}\text { Wave spots are more popular than wind spots } \\
\text { and used to attract more people. If one beach } \\
\text { has both, it is more attractive from an } \\
\text { environmental point of view than those ones } \\
\text { that only have one type of surfing spot. }\end{array}$ & 2 & $\mu_{2}=2.0000$ & Qualitative \\
\hline Wave spots & List the number of wave spots. & $\begin{array}{l}\text { Wave-based surfing types are more popular } \\
\text { than wind-based types. Thus, the variety of } \\
\text { these spots provide more potential to attract } \\
\text { more demand to the beach. }\end{array}$ & 3 & $\mu_{3}=1.5000$ & Quantitative \\
\hline Type of seabed (sandy or rocky) & Identify the type of seabed. & $\begin{array}{l}\text { Sandy seabed is better for beginners and can } \\
\text { house more types of surfing than rocky } \\
\text { seabed, which is more sensitive. }\end{array}$ & 4 & $\mu_{4}=1.2500$ & Quantitative \\
\hline Wind spots & List the number of wind spots. & $\begin{array}{l}\text { Wind spots attracts windsurfers as well as kite } \\
\text { surfers, although they are less popular sports } \\
\text { than wave-based surfing sports. }\end{array}$ & 5 & $\mu_{5}=0.5000$ & Quantitative \\
\hline Shark spotters & $\begin{array}{l}\text { Indicate whether there are shark } \\
\text { spotters in the beach or not. }\end{array}$ & $\begin{array}{l}\text { The existence of shark spotters in a beach } \\
\text { indicates that there are sharks and a rich } \\
\text { marine wildlife in it. Thus, it is more sensitive } \\
\text { than other beaches, although it is safer for } \\
\text { surfers due to a better information provided } \\
\text { by shark spotters. }\end{array}$ & 5 & $\mu_{5}=0.5000$ & Qualitative \\
\hline Water quality & $\begin{array}{l}\text { Identify the quality of the water of } \\
\text { the beach. }\end{array}$ & $\begin{array}{l}\text { The better the water of the beach is, the more } \\
\text { attractive it is to demand. }\end{array}$ & 5 & $\mu_{5}=0.5000$ & Qualitative \\
\hline Density white pop & $\begin{array}{l}\text { Calculate the potential density of } \\
\text { the local white population that } \\
\text { could access the beach. }\end{array}$ & $\begin{array}{l}\text { Historically, surfing has been practiced mainly } \\
\text { by the 'white' population in South Africa. The } \\
\text { more potential density, the more sensitive the } \\
\text { beach is, and a lower environmental indicator } \\
\text { is reached. }\end{array}$ & 5 & $\mu_{5}=0.5000$ & Quantitative * \\
\hline
\end{tabular}


Table 1. Cont.

\begin{tabular}{|c|c|c|c|c|c|}
\hline Environmental Indicators (Ien) & Assessment Criteria & Implications & Hierarchy & Multiplier & Data \\
\hline Density total pop & $\begin{array}{l}\text { Calculate the potential density of } \\
\text { the total local population that } \\
\text { could access the beach. }\end{array}$ & $\begin{array}{l}\text { Beach-goers in general are also users of the } \\
\text { same space as surfers, therefore, a higher } \\
\text { density of beach-goers indicates a lower level } \\
\text { of sustainability. }\end{array}$ & 5 & $\mu_{5}=0.5000$ & Quantitative* \\
\hline Fishing and angling & $\begin{array}{l}\text { Identify if there are any of these } \\
\text { facilities on the beach. }\end{array}$ & $\begin{array}{l}\text { Fishing and angling activities indicate the } \\
\text { existence of a rich marine life, thus, it is } \\
\text { potentially attractive to surfers who are keen } \\
\text { on fishing activities. }\end{array}$ & 5 & $\mu_{5}=0.5000$ & Qualitative \\
\hline Economic Indicators $(\mathrm{I} e)$ & Assessment criteria & Implications & Hierarchy & Multiplier & Data \\
\hline Surf companies & $\begin{array}{l}\text { Identify and list the number of surf } \\
\text { shops, retailers, and surf schools. }\end{array}$ & $\begin{array}{l}\text { Surf companies provide jobs and wealth to the } \\
\text { local community and services and information } \\
\text { to the tourists. }\end{array}$ & 1 & $\mu_{1}=2.0000$ & Quantitative \\
\hline Surf websites & $\begin{array}{l}\text { Identify and list the number of } \\
\text { online markers for each spot, } \\
\text { including wikis and } \\
\text { surf-forecast-related } \\
\text { websites and webcams. }\end{array}$ & $\begin{array}{l}\text { Surf websites (wikis and surf forecast tools) } \\
\text { provide information about weather conditions, } \\
\text { infrastructure, accessibility, dangers, existence } \\
\text { of localism, level of the spot (for beginners, } \\
\text { experts, etc.). }\end{array}$ & 2 & $\mu_{2}=1.7500$ & Quantitative \\
\hline Accommodation & $\begin{array}{l}\text { Find the number of } \\
\text { accommodation units in the } \\
\text { adjacent area, including hotels, } \\
\text { backpackers, lodges, etc. }\end{array}$ & $\begin{array}{l}\text { Accommodation infrastructure provides the } \\
\text { area with the potential to attract surf visitors } \\
\text { and represents one of the most important } \\
\text { sources of income for the area. It is also an } \\
\text { important generator of employment. }\end{array}$ & 3 & $\mu_{3}=1.5000$ & Quantitative \\
\hline Distance from airport & $\begin{array}{l}\text { Calculate the distance (or time) } \\
\text { from the international airport to } \\
\text { the beach. }\end{array}$ & $\begin{array}{l}\text { Short distances from the main type of } \\
\text { transportation used by both international and } \\
\text { national tourists provide the area with } \\
\text { potential to attract more visitors. }\end{array}$ & 4 & $\mu_{4}=1.2500$ & Quantitative* \\
\hline $\begin{array}{l}\text { Distance from accommodation } \\
\text { hub (Central Business District, } \\
\text { CBD) }\end{array}$ & $\begin{array}{l}\text { Calculate the distance from the } \\
\text { main accommodation hub in the } \\
\text { destination to the beach. }\end{array}$ & $\begin{array}{l}\text { Short distances from the main accommodation } \\
\text { hub for international and national tourists } \\
\text { provide the area with potential to attract more } \\
\text { visitors. }\end{array}$ & 5 & $\mu_{5}=0.4375$ & Quantitative * \\
\hline
\end{tabular}


Table 1. Cont.

\begin{tabular}{|c|c|c|c|c|c|}
\hline Environmental Indicators (Ien) & Assessment Criteria & Implications & Hierarchy & Multiplier & Data \\
\hline Parking & $\begin{array}{l}\text { Indicate the existence or not of } \\
\text { parking areas with direct access to } \\
\text { the beach. }\end{array}$ & $\begin{array}{l}\text { Surfers and accompanying visitors arriving by } \\
\text { car need parking facilities to access the surf } \\
\text { spot easily. It is also a place for social } \\
\text { gathering. Safe and good parking facility areas } \\
\text { have the potential to attract more visitors. }\end{array}$ & 5 & $\mu_{5}=0.4375$ & Qualitative \\
\hline Train stop & $\begin{array}{l}\text { Identify if there is any train stop in } \\
\text { the area ( } 3 \mathrm{~km} \text { around). }\end{array}$ & $\begin{array}{l}\text { The existence of train stops adds a better } \\
\text { connection to the area from CBD. }\end{array}$ & 5 & $\mu_{5}=0.4375$ & Qualitative \\
\hline Blue flag & $\begin{array}{l}\text { Identify and list the beaches } \\
\text { awarded with Blue Flags. }\end{array}$ & $\begin{array}{l}\text { Blue Flags are significant markers that provide } \\
\text { the beach with a recognized eco-label of } \\
\text { quality that attracts more visitors. }\end{array}$ & 5 & $\mu_{5}=0.4375$ & Qualitative \\
\hline Picnic area & $\begin{array}{l}\text { Identify if there are any of these } \\
\text { facilities on the beach. }\end{array}$ & $\begin{array}{l}\text { Picnic and braai (barbecue) areas have the } \\
\text { potential to attract groups (friends and } \\
\text { families) and visitors for a longer time. }\end{array}$ & 5 & $\mu_{5}=0.4375$ & Qualitative \\
\hline Tidal pool & $\begin{array}{l}\text { Identify whether there is a tidal } \\
\text { pool in the area or not. }\end{array}$ & $\begin{array}{l}\text { Tidal pools have the potential to attract } \\
\text { families and surfers' companions. }\end{array}$ & 5 & $\mu_{5}=0.4375$ & Qualitative \\
\hline Boat launch slipway & $\begin{array}{l}\text { Identify if there is a boat launch } \\
\text { slipway on the beach. }\end{array}$ & $\begin{array}{l}\text { Boat launch slipways allow surfers to practice } \\
\text { big wave surfing since those waves are ridden } \\
\text { aided by the power of a jet ski. }\end{array}$ & 5 & $\mu_{5}=0.4375$ & Qualitative \\
\hline Social Indicators (Is) & Assessment Criteria & Implications & Hierarchy & Multiplier & Data \\
\hline Total infections & $\begin{array}{l}\text { Identify the number of total } \\
\text { infections in the area and compare } \\
\text { it with the maximum of } \\
\text { the subdistricts. }\end{array}$ & $\begin{array}{l}\text { The total number of infections allows one to } \\
\text { know how the area has been affected } \\
\text { by the pandemic. }\end{array}$ & 1 & $\mu_{1}=2.0000$ & Quantitative* \\
\hline $\begin{array}{l}\text { Infections within the last } 14 \\
\text { days }\end{array}$ & $\begin{array}{l}\text { Identify the number of infections } \\
\text { within the last } 14 \text { days and } \\
\text { compare it with the subdistricts. }\end{array}$ & $\begin{array}{l}\text { The number of infections within the last } 14 \\
\text { days allows institutions and individuals to } \\
\text { know how the pandemic has developed in the } \\
\text { last two weeks and react if the } \\
\text { number increases. }\end{array}$ & 2 & $\mu_{2}=1.7500$ & Quantitative* \\
\hline
\end{tabular}


Table 1. Cont.

\begin{tabular}{|c|c|c|c|c|c|}
\hline Environmental Indicators (Ien) & Assessment Criteria & Implications & Hierarchy & Multiplier & Data \\
\hline Surf clubs & $\begin{array}{l}\text { Identify surf clubs that have access } \\
\text { and use the area on a regular basis. }\end{array}$ & $\begin{array}{l}\text { Surf clubs have the potential to provide better } \\
\text { collaboration and communication amongst } \\
\text { surfers about rules and hazards in the area. }\end{array}$ & 3 & $\mu_{3}=1.5000$ & Quantitative \\
\hline Lifesavers' clubs & $\begin{array}{l}\text { Identify the lifesavers' clubs that } \\
\text { have access and use the } \\
\text { area regularly. }\end{array}$ & $\begin{array}{l}\text { Lifesavers can promote safety and awareness } \\
\text { about potential hazards for beach-goers and } \\
\text { surfers as well as awareness about the } \\
\text { potential environmental damages to the area. }\end{array}$ & 4 & $\mu_{4}=1.2500$ & Qualitative \\
\hline Toilets & $\begin{array}{l}\text { Identify whether there are showers } \\
\text { and bathrooms in the area. }\end{array}$ & $\begin{array}{l}\text { Showers and toilets are important elements } \\
\text { that allow surfers to clean their equipment } \\
\text { and allow beach-goers to feel better after a } \\
\text { beach day. They also promote hygiene and } \\
\text { interaction. }\end{array}$ & 5 & $\mu_{5}=0.4375$ & Qualitative \\
\hline Access for disabled & $\begin{array}{l}\text { Identify if there is access for } \\
\text { disabled people. }\end{array}$ & $\begin{array}{l}\text { Interaction between practitioners of adapted } \\
\text { surfing and regular surfing allows community } \\
\text { to enhance relationships. }\end{array}$ & 5 & $\mu_{5}=0.4375$ & Qualitative \\
\hline $\begin{array}{l}\text { Police stations(within the same } \\
\text { major suburb) }\end{array}$ & $\begin{array}{l}\text { Identify if there is any Police } \\
\text { station nearby ( } 3 \mathrm{~km} \text { around). }\end{array}$ & $\begin{array}{l}\text { Police stations in the area ensure a rapid } \\
\text { response in case of emergency. }\end{array}$ & 5 & $\mu_{5}=0.4375$ & Qualitative \\
\hline Hospitals & $\begin{array}{l}\text { Identify whether there is a hospital } \\
\text { nearby ( } 3 \mathrm{~km} \text { around) or not. }\end{array}$ & $\begin{array}{l}\text { Hospitals nearby ensure that in case of } \\
\text { emergency, the person with problems will } \\
\text { have first aid and proper treatment } \\
\text { in less time. }\end{array}$ & 5 & $\mu_{5}=0.4375$ & Qualitative \\
\hline Clinics & $\begin{array}{l}\text { Identify the number of clinics } \\
\text { nearby ( } 3 \mathrm{~km} \text { around). }\end{array}$ & $\begin{array}{l}\text { Clinics around ensure that in case of } \\
\text { emergency, the person with health problems } \\
\text { will have rapid first aid. }\end{array}$ & 5 & $\mu_{5}=0.4375$ & Quantitative \\
\hline Running & $\begin{array}{l}\text { Identify if the area is suited } \\
\text { for runners. }\end{array}$ & $\begin{array}{l}\text { Areas suitable for running help } \\
\text { in socialization. }\end{array}$ & 5 & $\mu_{5}=0.4375$ & Qualitative \\
\hline Pets allowed & Identify if dogs are allowed. & $\begin{array}{l}\text { Areas suitable for dogs and pets are spaces } \\
\text { of socialization. }\end{array}$ & 5 & $\mu_{5}=0.4375$ & Qualitative \\
\hline
\end{tabular}

$$
\text { * Inverted indicator: } \mathrm{I}_{n}-1 \times(-1) \text {. }
$$


Environmental indicators include different aspects of the main resource (surf spots) for surfing activities. First, as noted by Barbieri and Sotomayor [99], the variety of spots seems to be one of the most important factors. Second, the type of surfing spots (wave or wind) located on the beach is also an essential element, since it attracts different demand. In the same vein, the number of such types of spots is also important, since this indicates the carrying capacity of the beach, which depends on the number of spots [100]. Regarding economic indicators, twelve have been chosen based on their importance for demand. From accessibility items (distance to the main sources of tourists and public transportation), infrastructures (parking areas), and tourism accommodation, to the more specific items, such as surfing companies and information services. On the other hand, social aspects include two indicators related to the current COVID-19 crisis and their data ('total infections' and 'last 14 days infections') collected during the first wave (5 July 2020 and from 20 June 2020 to 3 July 2020, respectively). In addition, social infrastructures like toilets and access for the disabled, as well as health infrastructures (clinics and hospitals) and safety facilities (police stations) are included.

On the one hand, in the case of each individual quantitative indicator, it has been calculated using the relative method (see Equation (1)). Following this method, the maximum raw data scored by a beach is considered as a base for building the indicator (it indicates the max score: $100 \%$ ). On the other hand, for calculating the qualitative indicators, we have assigned 1 to the existence of certain items, while 0 indicates the absence of them. Thus, the maximum score reached depends on its corresponding multiplier $\left(\mu_{m}\right.$, see Equation (1) below). Therefore, it can vary from 2.2500 in the case of environmental indicators or 2.0000 for social and economic ones for the maximum level of hierarchy (1), to 0.5000 for environmental indicators and 0.4375 for social and economic ones for the minimum (5), as shown in Table 1 below.

$$
\mathrm{I}_{n}=\left(\text { Raw value } \mathrm{I}_{n} \div \text { Raw value } \mathrm{I}_{0}\right) \times \mu_{m}
$$

Equation (1). Individual indicators.

The sustainability indicators for each beach $\left(\mathrm{I}_{n}\right)$ have been calculated implementing the weighted average of relatives method using Equation (2) below.

$$
\mathrm{I}_{\text {Total }(n)}=\alpha \mathrm{I} e_{n}+\beta \mathrm{I}_{n}+\gamma \operatorname{Ien}_{n}
$$

Equation (2). Sustainability indicator.

Where $\alpha(0.33)$ is the assigned weight to the economic-related indicator for each beach $\left(\mathrm{I} e_{n}\right), \beta(0.33)$ represents the allocated weight to the social-related indicator for each beach $\left(\mathrm{I} s_{n}\right)$, and $\gamma(0.34)$ corresponds to weight assigned to the environmental-related indicator

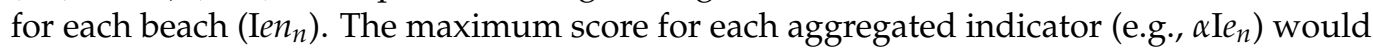
be 10 , as well as for the $\mathrm{I}_{\text {Total }(n)}$.

\section{Results}

\subsection{Surf Tourism Sustainability Indicators by Beach}

Fifteen beaches have been selected to illustrate the results (see Table 2). First, those that have ranked in the top ten, where all the subdistricts (Southern, Western, and Eastern) are included. Second, we have included three beaches located in underprivileged subdistricts like Mitchells Plain and Khayelitsha. Finally, we have added the beaches that have the lowest scores in the totals. 
Table 2. Illustrative economic, social, environmental, and total sustainability indicators.

\begin{tabular}{|c|c|c|c|c|c|c|}
\hline Beach & Position & $\begin{array}{l}\text { Subdistrict } \\
\text { (COVID-19) }\end{array}$ & $\mathrm{I} e$ & Is & Ien & $\mathbf{I}_{\text {Total }}$ \\
\hline \multicolumn{7}{|l|}{ Top $\mathbf{I}_{\text {Total }}$} \\
\hline Strand & 1 & Eastern & 4.93 & 5.03 & $9.10 *$ & $6.38 *$ \\
\hline Table View & 2 & Western & $7.33 *$ & 3.94 & 7.70 & 6.34 \\
\hline Big Bay & 3 & Western & 5.40 & 4.37 & 6.66 & 5.49 \\
\hline Surfer's Corner & 4 & Southern & 5.57 & 4.52 & 5.98 & 5.36 \\
\hline Milnerton & 5 & Western & 3.43 & $5.32 *$ & 6.11 & 4.97 \\
\hline Fish Hoek & 6 & Southern & 3.55 & 5.14 & 5.97 & 4.90 \\
\hline Hout Bay & 7 & Southern & 3.65 & 4.10 & 6.70 & 4.83 \\
\hline Muizenberg & 8 & Southern & 4.02 & 3.46 & 6.85 & 4.80 \\
\hline $\begin{array}{l}\text { Long Beach } \\
\text { (Kommetjie) }\end{array}$ & 9 & Southern & 3.18 & 3.08 & 7.21 & 4.52 \\
\hline Melkbosstrand & 10 & Western & 3.60 & 3.13 & 6.65 & 4.48 \\
\hline \multicolumn{7}{|l|}{ Middle $\mathbf{I}_{\text {Total }}$} \\
\hline Mnandi & 13 & $\begin{array}{l}\text { Mitchells } \\
\text { Plain }\end{array}$ & 3.60 & 4.74 & 4.55 & 4.30 \\
\hline Monwabisi & 23 & Khayelitsha & 2.59 & 4.10 & 4.16 & 3.62 \\
\hline Macassar & 34 & Khayelitsha & 2.56 & 2.92 & 4.18 & 3.23 \\
\hline \multicolumn{7}{|l|}{ Bottom $\mathbf{I}_{\text {Total }}$} \\
\hline Beta Beach & 48 & Western & 2.79 & 2.19 & 3.04 & 2.68 \\
\hline Klippies Bay & 49 & Eastern & 1.27 & 1.32 & 3.93 & 2.19 \\
\hline
\end{tabular}

* Highest score.

Strand appears to be the most potentially competitive beach for surf tourism, not only because of the high score reached in Ien, but also because it has very good scores in both Ie (4th) and Is (3rd). It has scored the maximum (1) in the four first individual Ien, with seven different surfing spots which include both wave-based (6) and wind-based (1). It is worth indicating that it has a sandy seabed, like the rest of the beaches positioned in the top ten, which could be a signal that this type of seabed is more indicated for surf tourism, as it allows surfing for many types of surfers (from beginners to experts).

Table View occupies one of the top positions of the most competitive beaches based on the score reached in terms of $\mathrm{I} e$, as it obtains very high figures in the three first items of the Ie. It has the second-best value for surf companies (counting a total of 10 companies) and surf websites (with a total of 19 websites referencing the spots), and the larger number of accommodation units (counting a total of 293 accommodation units) of the 49 beaches included in the study (see Table 3). It is also important to note that Table View has a high score in terms of Ien, since it shows high values for the first four individual items of this indicator. It has five different surfing spots, with both typologies: 3 wave-based and 2 wind-based. Big Bay is third in the top ten ranking, although it does not have the highest score in any of the aggregated individual indicators but a balanced record in all of them. Surfer's Corner is the first beach belonging to the Southern subdistrict that appears in the top 10, scoring higher numbers for Ie and Is than Big Bay, but having a lower figure in Ien, which is mainly due to the lack of wind-based spots, which indicates its specialization in wave-based surfing. The fifth position is occupied by Milnerton, being the third out of four beaches belonging to the Western subdistrict that appears in this classification. The fourth beach that belongs to the Western subdistrict is Melkbosstrand, which shares the same geographical position. It is interesting to note that none of the seaboard beaches (from Granger Bay to Beta, see Figure 2) have entered the top 10. On the other hand, it seems clear that there are two main areas where surfing activities are concentrated: Western (from Melkbosstrand to Milnerton), which has both wind-based and wave-based surfing activities, and Southern (which is more dispersed), which concentrates surfing activities from the beach that includes Fish Hoek and its harbor to Muizenberg, which mainly has wave-based surfing spots. 
Table 3. Top, middle, and bottom positions of illustrative beaches and individual economic, social and environmental indicators.

\begin{tabular}{|c|c|c|c|c|c|c|c|c|c|c|c|c|c|c|c|c|}
\hline \multirow[b]{2}{*}{ 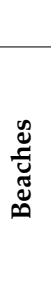 } & \multirow[t]{2}{*}{ Indicators } & \multicolumn{10}{|c|}{ Top 10} & \multicolumn{3}{|c|}{ Middle } & \multicolumn{2}{|c|}{ Bottom } \\
\hline & & $\begin{array}{l}\text { E్ } \\
\text { के }\end{array}$ & $\begin{array}{l}3 \\
\stackrel{0}{3} \\
\frac{0}{0} \\
\frac{0}{\pi}\end{array}$ & $\begin{array}{l}\vec{A} \\
\overrightarrow{0} \\
\overrightarrow{0}\end{array}$ & 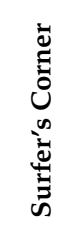 & 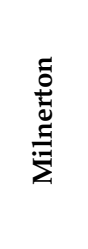 & 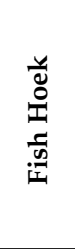 & 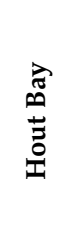 & 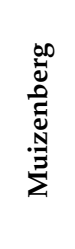 & 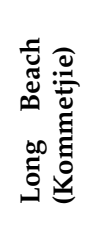 & 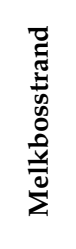 & 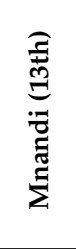 & 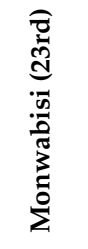 & 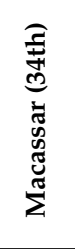 & صేّ & 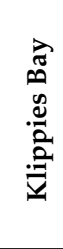 \\
\hline \multirow{11}{*}{ 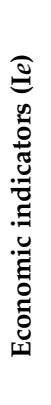 } & Surf companies & 0.18 & 0.91 & 0.45 & 1.00 & 0.18 & 0.09 & 0.18 & 0.09 & 0.09 & 0.09 & 0.00 & 0.00 & 0.00 & 0.00 & 0.00 \\
\hline & Surf websites & 0.70 & 0.95 & 1.00 & 0.55 & 0.25 & 0.35 & 0.35 & 0.45 & 0.65 & 0.40 & 0.10 & 0.15 & 0.15 & 0.05 & 0.15 \\
\hline & Distance from airport * & 0.50 & 0.57 & 0.49 & 0.54 & 0.71 & 0.44 & 0.51 & 0.54 & 0.24 & 0.35 & 0.78 & 0.62 & 0.62 & 0.61 & 0.11 \\
\hline & Distance from CBD * & 0.35 & 0.74 & 0.67 & 0.62 & 0.86 & 0.53 & 0.73 & 0.62 & 0.42 & 0.57 & 0.49 & 0.46 & 0.46 & 0.89 & 0.00 \\
\hline & Parking & 1.00 & 1.00 & 1.00 & 1.00 & 1.00 & 1.00 & 1.00 & 1.00 & 1.00 & 1.00 & 1.00 & 1.00 & 1.00 & 1.00 & 1.00 \\
\hline & Train stops & 1.00 & 0.00 & 0.00 & 1.00 & 0.00 & 1.00 & 0.00 & 1.00 & 0.00 & 0.00 & 1.00 & 1.00 & 0.00 & 0.00 & 0.00 \\
\hline & Bus stop & 0.29 & 1.00 & 0.67 & 1.00 & 1.00 & 1.00 & 0.67 & 1.00 & 0.75 & 1.00 & 0.00 & 0.00 & 0.00 & 1.00 & 0.00 \\
\hline & Blue flag & 0.00 & 0.00 & 0.00 & 0.00 & 0.00 & 1.00 & 0.00 & 1.00 & 0.00 & 1.00 & 1.00 & 0.00 & 0.00 & 0.00 & 0.00 \\
\hline & Picnic area & 0.50 & 0.00 & 0.00 & 0.00 & 0.00 & 0.00 & 0.00 & 0.00 & 0.00 & 0.00 & 1.00 & 1.00 & 1.00 & 0.00 & 1.00 \\
\hline & Tidal pool & 1.00 & 0.00 & 0.00 & 0.00 & 0.00 & 0.00 & 0.00 & 0.00 & 0.00 & 0.00 & 1.00 & 0.00 & 0.00 & 0.00 & 0.00 \\
\hline & Boat launch slipway & 1.00 & 1.00 & 1.00 & 0.00 & 0.00 & 0.00 & 1.00 & 0.00 & 1.00 & 1.00 & 0.00 & 0.00 & 1.00 & 0.00 & 0.00 \\
\hline \multirow{12}{*}{ 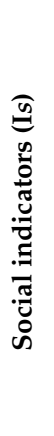 } & $\begin{array}{l}\text { Last } 14 \text { days infections (from } 2 \\
\text { June to } 3 \text { July) * }\end{array}$ & 0.19 & 0.36 & 0.36 & 0.33 & 0.36 & 0.33 & 0.33 & 0.33 & 0.33 & 0.36 & 0.39 & 0.48 & 0.48 & 0.36 & 0.19 \\
\hline & Total Infections (5 July) * & 0.29 & 0.34 & 0.34 & 0.31 & 0.34 & 0.31 & 0.31 & 0.31 & 0.31 & 0.34 & 0.30 & 0.20 & 0.20 & 0.34 & 0.29 \\
\hline & Surfclubs & 0.67 & 0.00 & 0.33 & 1.00 & 0.33 & 0.33 & 0.67 & 0.00 & 0.33 & 0.00 & 0.00 & 0.00 & 0.00 & 0.00 & 0.00 \\
\hline & Livesavers clubs & 1.00 & 0.00 & 1.00 & 0.00 & 1.00 & 1.00 & 0.00 & 0.00 & 0.00 & 0.00 & 1.00 & 1.00 & 0.00 & 0.00 & 0.00 \\
\hline & Lifeguards & 1.00 & 0.00 & 1.00 & 0.00 & 1.00 & 1.00 & 1.00 & 1.00 & 0.00 & 1.00 & 1.00 & 1.00 & 1.00 & 0.00 & 0.00 \\
\hline & Toilets & 1.00 & 1.00 & 1.00 & 1.00 & 1.00 & 1.00 & 1.00 & 1.00 & 1.00 & 0.00 & 0.00 & 1.00 & 1.00 & 1.00 & 1.00 \\
\hline & Access for people with disabilities & 0.00 & 1.00 & 1.00 & 1.00 & 0.00 & 0.00 & 0.00 & 0.00 & 0.00 & 1.00 & 1.00 & 0.00 & 0.00 & 0.00 & 0.00 \\
\hline & Police stations & 1.00 & 1.00 & 0.00 & 1.00 & 1.00 & 1.00 & 1.00 & 1.00 & 1.00 & 1.00 & 1.00 & 1.00 & 1.00 & 1.00 & 0.00 \\
\hline & Hospitals & 1.00 & 1.00 & 0.00 & 0.00 & 1.00 & 1.00 & 0.00 & 0.00 & 0.00 & 0.00 & 1.00 & 0.00 & 0.00 & 0.00 & 0.00 \\
\hline & Clinics & 0.33 & 0.00 & 0.00 & 0.17 & 0.17 & 0.00 & 0.33 & 0.17 & 0.17 & 0.17 & 1.00 & 0.50 & 0.67 & 0.00 & 0.00 \\
\hline & Running & 0.00 & 1.00 & 0.00 & 0.00 & 0.00 & 0.00 & 0.00 & 1.00 & 0.00 & 0.00 & 0.00 & 0.00 & 0.00 & 0.00 & 0.00 \\
\hline & Pets allowed & 0.00 & 1.00 & 0.00 & 1.00 & 1.00 & 1.00 & 1.00 & 1.00 & 1.00 & 1.00 & 0.00 & 0.00 & 0.00 & 0.00 & 0.00 \\
\hline
\end{tabular}


Table 3. Cont.

\begin{tabular}{|c|c|c|c|c|c|c|c|c|c|c|c|c|c|c|c|c|}
\hline \multirow[b]{2}{*}{ 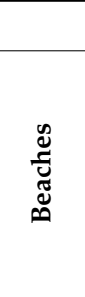 } & \multirow[t]{2}{*}{ Indicators } & \multicolumn{10}{|c|}{ Top 10} & \multicolumn{3}{|c|}{ Middle } & \multicolumn{2}{|c|}{ Bottom } \\
\hline & & 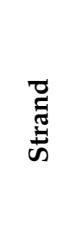 & 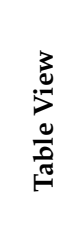 & $\begin{array}{l}\overrightarrow{0} \\
\stackrel{0}{00} \\
\stackrel{00}{0}\end{array}$ & 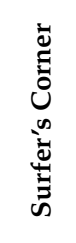 & 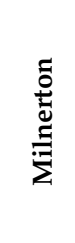 & 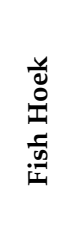 & 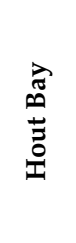 & 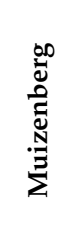 & 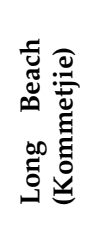 & 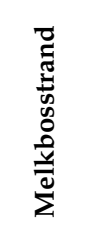 & 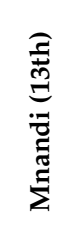 & 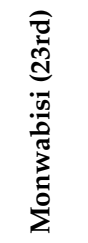 & 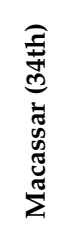 & صึّ & 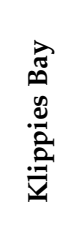 \\
\hline \multirow{9}{*}{ 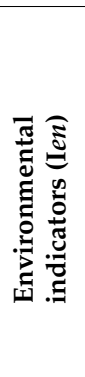 } & Variety spot & 1.00 & 0.71 & 0.43 & 0.29 & 0.29 & 0.29 & 0.43 & 0.43 & 0.57 & 0.57 & 0.14 & 0.14 & 0.14 & 0.14 & 0.14 \\
\hline & Wave and or wind spots & 1.00 & 1.00 & 1.00 & 1.00 & 1.00 & 1.00 & 1.00 & 1.00 & 1.00 & 0.50 & 0.50 & 0.50 & 0.50 & 0.50 & 0.50 \\
\hline & Type of seabed (sandy or rocky) & 1.00 & 1.00 & 1.00 & 1.00 & 1.00 & 1.00 & 1.00 & 1.00 & 1.00 & 1.00 & 1.00 & 1.00 & 1.00 & 0.50 & 0.50 \\
\hline & Windspots & 0.50 & 1.00 & 0.50 & 0.50 & 0.50 & 0.50 & 0.50 & 0.50 & 0.50 & 0.00 & 0.00 & 0.00 & 0.50 & 0.00 & 0.00 \\
\hline & Shark spotters & 1.00 & 0.50 & 0.50 & 1.00 & 0.50 & 1.00 & 0.50 & 0.50 & 0.50 & 0.50 & 0.50 & 0.50 & 0.50 & 0.50 & 1.00 \\
\hline & Water quality & 0.25 & 0.75 & 1.00 & 0.38 & 1.00 & 0.25 & 0.50 & 0.38 & 1.00 & 0.75 & 0.50 & 0.25 & 0.25 & 0.25 & 1.00 \\
\hline & Density white pop * & 0.99 & 0.97 & 0.94 & 0.91 & 0.98 & 0.95 & 0.99 & 0.96 & 0.95 & 0.99 & 1.00 & 1.00 & 1.00 & 0.63 & 0.84 \\
\hline & $\begin{array}{l}\text { Density total pop general } \\
\text { beach goers* }\end{array}$ & 0.96 & 0.97 & 0.95 & 0.90 & 0.96 & 0.95 & 0.98 & 0.95 & 0.90 & 0.99 & 0.96 & 0.93 & 0.97 & 0.31 & 0.62 \\
\hline & Fishing and angling & 0.50 & 0.00 & 0.00 & 0.00 & 0.00 & 0.00 & 0.50 & 1.00 & 0.00 & 1.00 & 0.50 & 0.00 & 0.00 & 0.00 & 0.00 \\
\hline
\end{tabular}

* Inverted indicator: $I_{n}-1 \times(-1)$ 
Regarding social indicators, Milnerton scores the maximum, in part, due to the lowest number of infections, but also because it scores in 10 out of 12 items. Additionally, it seems interesting to highlight the good position of Mnandi (4th) and Monwabisi (9th) in the aggregated indicator, since they are not included in the general top 10 (13th and 23rd, respectively) but belong to unprivileged areas (Mitchells Plain and Khayelitsha, respectively) avoided by the traditional tourism routes. It is also interesting to note that Strand is the only beach that does not belong to the Southern or Western subdistrict, in which most beaches are concentrated (39\%, 80\%) (see Table 4).

Table 4. Economic, social, environmental, and total sustainability indicators by subdistrict.

\begin{tabular}{ccccccc}
\hline Subdistrict & $\begin{array}{c}\text { Number of } \\
\text { Beaches }\end{array}$ & Percentage & Ie & Is & Ien & Total \\
\hline Southern (17, 35\%) & 17 & $35 \%$ & 3.01 & 3.21 & $\mathbf{5 . 3 7} *$ & $\mathbf{3 . 8 8} *$ \\
Western (22, 45\%) & $\mathbf{2 2 *}$ & $\mathbf{4 5 \%} *$ & $\mathbf{3 . 5 2} *$ & 2.99 & 4.71 & 3.75 \\
Khayelitsha + Mitchells Plain (3, 6\%) & 3 & $6 \%$ & 2.91 & $\mathbf{3 . 9 2} *$ & 4.30 & 3.72 \\
Eastern (7, 14\%) & 7 & $14 \%$ & 2.43 & 2.83 & 5.27 & 3.53 \\
\hline * Highest score. & & & & & &
\end{tabular}

${ }^{*}$ Highest score.

\subsection{Surf Tourism Sustainability Indicators by Subdistrict}

Regarding the results of the aggregated indicators (Ie, Is, and Ien) by subdistrict, they show that each of them has a distinctive competitive advantage. First, the Southern subdistrict scores the maximum in Ien, the second score related to Ie (where Surfers' Corner stand out), and Is, which makes a balanced score in general. Second, Western scores the highest Ie of the group, boosted by Table View and Big Bay. Third, the three beaches corresponding to the unprivileged areas of Mitchells Plain and Khayelitsha score together the best value for Is. Finally, the Eastern area scored the lowest Ie and Is, but the second highest Ien (boosted by Strand).

\section{Discussion and Conclusions}

This study has investigated the tourism potential and competitiveness of Cape Town as a surf destination using a weighting indicators method to compare the different surftourism-related resources within the area. Surf tourism involves not only wave-based surfing activities, but also wind-based and self-propelled activities, which have experienced growth due to the changes experienced within societies (individualism, use of new technologies, seeking for freedom and nature). This method has been already employed in surf tourism in Thailand [24] and in Cape Town [25], although the last one was only focused on the socio-economic issues with a lack of environmental indicators. In the case of the works of Martin [21], Martin and Assenov [22,24], and Martin and Ritchie [23], the measuring and weights were developed together with the stakeholders, while this article lacks such methodology. Additionally, those pieces of research added the concept of governance and were focused on conservation issues, but did not link them with the concept of tourism competitiveness. Thus, the results obtained by Martin and Ritchie were highly focused on 'planners perceptions about what concerns tourists', which 'might not correspond with those of the tourist consumer' ([23], p. 20). Regarding the latter, they obtained 'high to very high' weights for environmental parameters, 'and so differences in unweighted and weighted scores are very sensitive to small differences' ([23], p. 15). In order to avoid that limitation, this study employed a different perspective, using previous research about what concerns surf tourists (e.g., the work of Barbieri and Sotomayor [99]). On the other hand, the work of Cerezo and Galacho [67] found certain correlations between the number of natural resources and a higher eco-tourism potentiality in the studied area (municipalities within and around the borders of the Sierra de las Nieves natural park), as they assigned higher weights and multipliers to tourism resources and natural resources, respectively. Similarly, in Cape Town, the subdistrict with the better score is the Southern, which has fewer beaches than the second-best-scoring one, although it has a higher number of surf spots (40), which is the main natural resource for surf tourism. 
The analysis of the beaches individually seems to indicate that there are many differences between them, with a wide choice of different types of qualities. In this vein, Strand and Table View have both excelled in terms of environmental sustainability (first and second positions, respectively), as they offer a variety of wave-based and wind-based spots. Then, in third position is Long Beach (Kommetjie). These results could indicate that those beaches can be promoted to attract environmentally sensitive surf tourists. On the other hand, Table View obtained the best I $e$, which is basically due to the existence of a wide offer of both surf-related companies and accommodation units around the beach, followed by Surfers' Corner and Big Bay, suggesting these are the most competitive beaches in terms of economic indicators. These beaches seem to be interesting for targeting surf tourists if the institutions involved in tourism development are concerned about increasing the economic return of tourism. On the other hand, from a social point of view, Milnerton, Fish Hoek, and Strand scored the first, second, and third, respectively, and appear to be interesting for attracting socially sensitive tourists.

In another vein, this study has emphasized how, historically, South Africa in general and Cape Town in particular have been suffering a series of discriminatory and segregationist laws that have shaped the spatial distribution of the population. This is reflected in how the white population surrounds the beaches with better economic indicators (e.g., surfingrelated and touristic services and products are mainly in the Western subdistrict) and environmental indicators (e.g., in terms of variety of spots, the incidence of which is higher in the Southern subdistrict). Nonetheless, it is interesting to highlight that Khayelitsha and Mitchells Plain (with a majority of African Black and Coloured populations, respectively) have good social indicators, maybe in part because the first wave of the pandemic has been controlled in a better way, but also because there are more social infrastructures than in the rest of areas, showing that Cape Town and other governmental institutions responsible for providing them have invested in such infrastructures in order to prevent the health and crime issues that affect those communities. Additionally, this study has highlighted economic, social, and environmental weaknesses of some beaches in relation to surf tourism. This information is potentially useful for the institutions responsible for sport and tourism in the area (local, regional, and national), since it provides knowledge about the beaches and the associated interventions required.

The limitations of the study are various. First, the method used to determine indicators, weights, and hierarchies is subjective and has been based on the researchers' expertise in the field as a surfer (Author 1), as a reputable international academic in sport geography and active sport tourism (Author 2), and as an internationally recognized academic in sport tourism (Author 3), respectively. Second, the seasonality and consistency of the surf spots has not being take into account, although both are important factors [100] that could explain the affinity of surfers and tourists for the surf spots. Third, although we have included police stations as indicators for safety and security factors, the incidence of criminality has not been included, which could explain the lack of tourists' affinity for certain areas (e.g., Khayelitsha and Mitchells Plain). Fourth, the real data related to COVID-19 are very dynamic, although the data used depict a fixed picture only. Fifth, the surf events and surf-related nostalgia/heritage products have not been explored. Finally, the figures related to accommodation have been measured in units, when the most accurate way would to analyze the number of rooms or beds available in an area, and the figures were collected at the beginning of 2019 (one year before the pandemic), as were the figures for the surf companies, which may have varied due to the COVID-19 crisis.

Future studies should solve the limitations pointed out above. Additionally, they could include the opinion of a broader range stakeholders (e.g., surf companies, government, surf tourists, etc.) in the construction of the indicators.

Author Contributions: Conceptualization, R.M.-G., K.S. and A.-M.L.-G.; methodology, R.M.-G.; software, R.M.-G.; validation, K.S. and A.-M.L.-G.; formal analysis, R.M.-G.; investigation, R.M.-G.; resources, R.M.-G.; data curation, R.M.-G.; writing—original draft preparation, Martín-González, R; writing—review and editing, K.S. and A.-M.L.-G.; visualization, R.M.-G.; supervision, K.S. and 
A.-M.L.-G.; funding acquisition, R.M.-G. All authors have read and agreed to the published version of the manuscript.

Funding: This research was funded by the EUROSA programme, Erasmus Mundus +.

Institutional Review Board Statement: The study was conducted according to the guidelines of the Declaration of Helsinki and approved by the Faculty of Business and Management Sciences Ethics Committee of the Cape Peninsula University of Technology (Protocol: Cape Peninsula University of Technology Guide to Post Graduate Studies and Guidelines for Research Proposals, May 2015).

Informed Consent Statement: Informed consent was obtained from all subjects involved in the study.

Data Availability Statement: Not applicable.

Conflicts of Interest: The authors declare no conflict of interest.

\section{References}

1. Ritchie, B.; Adair, D. The growing recognition of sport tourism. Curr. Issues Tour. 2002, 5, 1-6. [CrossRef]

2. Weed, M. Progress in sports tourism research? A meta-review and exploration of futures. Tour. Manag. 2009, 30, 615-628. [CrossRef]

3. Jiménez-García, M.; Ruiz-Chico, J.; Peña-Sánchez, A.R.; López-Sánchez, J.A. A bibliometric analysis of sports tourism and sustainability (2002-2019). Sustainability 2020, 12, 2840. [CrossRef]

4. Gössling, S.; Scott, D.; Hall, C.M. Pandemics, tourism and global change: A rapid assessment of COVID-19. J. Sustain. Tour. 2020, 29, 1-20. [CrossRef]

5. Aburumman, A.A. COVID-19 impact and survival strategy in business tourism market: The example of the UAE MICE industry. Humanit. Soc. Sci. Commun. 2020, 7, 141. [CrossRef]

6. Slater, S.J.; Christiana, R.W.; Gustat, J. Recommendations for keeping parks and green space accessible for mental and physical health during COVID-19 and other pandemics. Prev. Chronic Dis. 2020, 17, E59. [CrossRef] [PubMed]

7. Frühauf, A.; Schnitzer, M.; Schobersberger, W.; Weiss, G.; Kopp, M. Jogging, nordic walking and going for a walk-inter-disciplinary recommendations to keep people physically active in times of the Covid-19 lockdown in Tyrol, Austria. Curr. Issues Sport Sci. 2020. [CrossRef]

8. Rice, W.; Meyer, C.; Lawhon, B.; Taff, B.D.; Mateer, T.; Reigner, N.; Newman, P. The COVID-19 pandemic is changing the way people recreate outdoors: Preliminary report on a national survey of outdoor enthusiasts amid the COVID-19 pandemic. J. Urban Ecol. 2020, 6. [CrossRef]

9. Porter, B.A.; Usher, L.E. Sole Surfers? Exploring family status and travel behaviour among surf travellers. Ann. Leis. Res. 2019, 22, 424-443. [CrossRef]

10. Hritz, N.; Franzidis, A.F. Exploring the economic significance of the surf tourism market by experience level. J. Destin. Mark. Manag. 2018, 7, 164-169. [CrossRef]

11. Gardiner, S. Chinese learn to surf: Learning ambidexterity and tourism experience innovation. J. China Tour. Res. 2021, 17, 142-162. [CrossRef]

12. Towner, N. Community participation and emerging surfing tourism destinations: A case study of the Mentawai Islands. J. Sport Tour. 2016, 20, 1-19. [CrossRef]

13. Mach, L. Surf-for-Development: An exploration of program recipient perspectives in Lobitos, Peru. J. Sport Soc. Issues 2019, 43, 438-461. [CrossRef]

14. Brody, S. Sustainable stoke: Liberia. In Sustainable Stoke: Transitions to Sustainability in the Surfing World; Borne, G., Ponting, J., Eds.; University of Plymouth Press: Plymouth, UK, 2015; pp. 146-153; ISBN 978-1-84102-341-0.

15. Larson, L.R.; Usher, L.E.; Chapmon, T. Surfers as environmental stewards: Understanding place-protecting behavior at Cape Hatteras National Seashore. Leis. Sci. 2017, 48, 1-24. [CrossRef]

16. Reineman, D.R.; Ardoin, N.M. Sustainable tourism and the management of nearshore coastal places: Place attachment and disruption to surf-spots. J. Sustain. Tour. 2018, 26, 325-340. [CrossRef]

17. Zietsman, G. \#ItsAllStillHere: Cape Town Dropping into Surf Tourism + Best Waves in SA. Traveller24. 2018. Available online: https: //www.news24.com/news24/travel/itsallstillhere-cape-town-dropping-into-surf-tourism-best-waves-in-sa-20180911 (accessed on 16 May 2021).

18. Martin-Gonzalez, R.; Luque-Gil, A.M.; Swart, K. Surf tourism knowledge system: A conceptual approach. In Tourism, Hospitality and Digital Transformation: Strategic Management Aspects; Tajeddini, K., Ratten, V., Merkle, T., Eds.; Routledge: Abingdon, UK, 2019; pp. 175-220; ISBN 978-0-367-15000-6.

19. Laderman, S. Beyond green: Sustainability, freedom and labour of the surf industry. In Sustainable Stoke: Transitions to Sustainability in the Surfing World; Borne, G., Ponting, J., Eds.; University of Plymouth Press: Plymouth, UK, 2015; pp. 80-83; ISBN 978-1-84102-341-0.

20. Butt, T. Surf travel: The elephant in the room. In Sustainable Stoke: Transitions to Sustainability in the Surfing World; Borne, G., Ponting, J., Eds.; University of Plymouth Press: Plymouth, UK, 2015; pp. 200-213; ISBN 978-1-84102-341-0. 
21. Martin, S.A. A Surf Resource Sustainability Index for Surf Site Conservation and Tourism Management. Ph.D. Thesis, Prince of Songkla University, Hat Yai, Thailand, 2013.

22. Martin, S.A.; Assenov, I. Investigating the importance of surf resource sustainability indicators: Stakeholder perspectives for surf tourism planning and development. Tour. Plan. Dev. 2014, 11, 127-148. [CrossRef]

23. Martin, S.A.; Ritchie, R. A social science index and conceptual framework for assigning weights in surf tourism planning and development. Tour. Plan. Dev. 2019, 16, 281-303. [CrossRef]

24. Martin, S.A.; Assenov, I. Measuring the conservation aptitude of surf beaches in Phuket, Thailand: An application of the surf resource sustainability index. Int. J. Tour. Res. 2015, 17, 105-117. [CrossRef]

25. Martín-González, R.; Swart, K.; Luque-Gil, A.M. The Covid-19 crisis and the 'new' normality of surf tourism in Cape Town, South Africa. Afr. J. Hosp. Tour. Leis. 2021, 10, 194-213. [CrossRef]

26. Bianchi, R. The political economy of tourism development: A critical review. Ann. Tour. Res. 2018, 70, 88-102. [CrossRef]

27. Cornelissen, S. The Global Tourism System: Governance, Development and Lessons from South Africa; Ashgate Publishing Ltd.: New York, NY, USA, 2005; ISBN 978-1-138-24706-2.

28. Martin, S.A.; O’Brien, D. Surf resource system boundaries. In Sustainable Surfing; Borne, G., Ponting, J., Eds.; Routledge: New York, NY, USA, 2017; ISBN 978-1-315-68023-1.

29. Poon, A. Tourism, Technology and Competitive Strategies; CAB International: Wallingford, UK, 1993 ; ISBN 0851987516.

30. Crouch, G.I.; Ritchie, J.R.B. Tourism, competitiveness, and societal prosperity. J. Bus. Res. 1999, 44, 137-152. [CrossRef]

31. Sánchez Rivero, M.; Sánchez Martín, J.M.; Rengifo Gallego, J.I. Methodological approach for assessing the potential of a rural tourism destination: An application in the province of Cáceres (Spain). Curr. Issues Tour. 2016, 19, 1084-1102. [CrossRef]

32. Standeven, J.; De Knop, P. Sport Tourism; Human Kinetics: Mishawaka, IN, USA, 1999; ISBN 978-0873228534.

33. Weed, M.; Bull, C. Sports Tourism: Participants, Policy and Providers, 2nd ed.; Elsevier/Butterworth-Heinemann: Amsterdam, The Netherlands, 2009; ISBN 978-0750683753.

34. Higham, J. Sport tourism: A perspective article. Tour. Rev. 2021, 76, 64-68. [CrossRef]

35. García-Ferrando, M.; Llopis-Goig, R. Encuesta Sobre Los Hábitos Deportivos En España 2010-Ideal Democrático y Bienestar Personal [Democratic Ideal and Personal Well-Being. Survey on Sport Participation in Spain 2010]; Catálogo de Publicaciones de la Administración General del Estado: Madrid, Spain, 2011; ISBN 978-84-7476-566-3.

36. Weed, M. The role of the interface of sport and tourism in the response to the COVID-19 Pandemic. J. Sport Tour. 2020, $24,79-92$. [CrossRef]

37. Duglio, S.; Beltramo, R. Estimating the economic impacts of a small-scale sport tourism event: The case of the Italo-Swiss Mountain Trail CollonTrek. Sustainability 2017, 9, 343. [CrossRef]

38. Van Rheenen, D.; Cernaianu, S.; Sobry, C. Defining sport tourism: A content analysis of an evolving epistemology. J. Sport Tour. 2017, 21, 75-93. [CrossRef]

39. Weed, M. After 20 Years, what are the big questions for sports tourism research? J. Sport Tour. 2015, 19, 1-4. [CrossRef]

40. Deery, M.; Jago, L. The management of sport tourism. Sport Soc. 2005, 8, 378-389. [CrossRef]

41. Hinch, T.; Higham, J. Sport tourism: A framework for research. Int. J. Tour. 2001, 3, 45-58. [CrossRef]

42. Gibson, H.J. Sport tourism: A critical analysis of research. Sport Manag. Rev. 1998, 1, 45-76. [CrossRef]

43. Hinch, T.; Higham, J.; Sant, S.-L. Taking stock of sport tourism research. In The Wiley Blackwell Companion to Tourism; Lew, A.A., Hall, C.M., Williams, A.M., Eds.; John Wiley \& Sons, Ltd.: Oxford, UK, 2014; pp. 413-424. ISBN 978-1118474488.

44. Weed, M. Sports tourism theory and method-Concepts, issues and epistemologies. Eur. Sport Manag. Q. 2005, 5, 229-242. [CrossRef]

45. Wheaton, B. Introducing the consumption and representation of lifestyle sports. Sport Soc. 2010, 13, 1057-1081. [CrossRef]

46. Hall, C.M. Adventure, sport and health tourism. In Special Interest Tourism; Weiler, B., Hall, C.M., Eds.; Belhaven Press: London, UK, 1992; pp. 141-158.

47. Ramshaw, G.; Gammon, S.J. Towards a critical sport heritage: Implications for sport tourism. J. Sport Tour. 2017, 21, 115-131. [CrossRef]

48. Martin, S.; Assenov, I. The genesis of a new body of sport tourism literature: A systematic review of surf tourism research (1997-2011). J. Sport Tour. 2012, 17, 257-287. [CrossRef]

49. Palladini, D. Smart business: Linking environmental health to corporate wellbeing. In Sustainable Stoke: Transitions to Sustainability in the Surfing World; Borne, G., Ponting, J., Eds.; University of Plymouth Press: Plymouth, UK, 2015; pp. 30-33. ISBN 978-1-84102-341-0.

50. Lazarow, N. The value of coastal recreational resources: A case study approach to examine the value of recreational surfing to specific locales. J. Coast. Res. 2007, 50, 12-20.

51. Doering, A. From He'e Nalu to olympic sport-a century of surfing evolution. In Sport Tourism Development; Higham, J., Ed.; Channel View Publications: Bristol, UK, 2018; pp. 200-203; ISBN 978-1-84541-654-6.

52. Nendel, J. Surfing in early twentieth-century Hawaii: The appropriation of a transcendent experience to competitive American sport. Int. J. Hist. Sport 2009, 26, 2432-2446. [CrossRef]

53. Augustin, J. Emergence of surfing resorts on the Aquitaine Littoral. Geogr. Rev. 1998, 88, 587-595. [CrossRef]

54. Laderman, S. Empire in Waves: A Political History of Surfing; University of California Press: London, UK, 2014; Volume 1; ISBN 978-0-520-27911-7. 
55. Stranger, M. Surface and substructure: Beneath surfing's commodified surface. Sport Soc. 2010, 13, 1117-1134. [CrossRef]

56. Booth, D. Nature sports: Ontology, embodied being, politics. Ann. Leis. Res. 2020, 23, 19-33. [CrossRef]

57. Martin-Gonzalez, R.; Swart, K.; Luque-Gil, A.M. A surfing-related sports (SRSs) taxonomy based on power and environment requirements. In Proceedings of the 27th European Sport Management Conference, Seville, Spain, 3-6 September 2019; pp. 434-435; ISBN 978-84-09-14068-8.

58. Mach, L.; Ponting, J.; Brown, J.; Savage, J. Riding waves of intra-seasonal demand in surf tourism: Analysing the nexus of seasonality and 21st century surf forecasting technology. Ann. Leis. Res. 2020, 23, 184-202. [CrossRef]

59. Able, A.; O'Brien, D. Negotiating communities: Sustainable cultural surf tourism. In Sustainable Stoke: Transitions to Sustainability in the Surfing World; Borne, G., Ponting, J., Eds.; University of Plymouth Press: Plymouth, UK, 2015; pp. 154-165; ISBN 978-1-84102-341-0.

60. Dedina, S.; Najera, E.; Plopper, Z.; Garcia, C. Surfing and coastal ecosystem conservation in Baja California, Mexico. In Sustainable Stoke: Transitions to Sustainability in the Surfing World; Borne, G., Ponting, J., Eds.; University of Plymouth Press: Plymouth, UK, 2015; pp. 166-171; ISBN 978-1-84102-341-0.

61. Thompson, G. Certain political considerations: South African competitive surfing during the International Sports Boycott. Int. J. Hist. Sport 2011, 28, 32-46. [CrossRef]

62. UNWTO. Indicators of Sustainable Development for Tourism Destinations: A Guidebook; UNWTO: Madrid, Spain, 2004; ISBN 978-92-844-0726-2.

63. UNWTO. What Tourism Managers Need to Know: A Practical Guide to the Development and Use of Indicators of Sustainable Tourism; UNWTO: Madrid, Spain, 1996; ISBN 978-9284401505.

64. Garret, R.; Latawiec, A.E. What are sustainability indicators for? In Sustainability Indicators in Practice; Latawiec, A.E., Ed.; De Gruyter Open Ltd.: Berlin, Germany, 2015; pp. 12-15; ISBN 978-3-11-045050-7.

65. Bassey, B.E. Transforming the Nigeria tourism industry through tourism entrepreneurial development. Afr. J. Bus. Manag. 2015, 9, 569-580. [CrossRef]

66. Olivares, D.L. La Evaluación de Los Recursos Territoriales Turísticos de Carácter Básico: El Caso de Las Palyas Del Norte de La Comunidad Valenciana. [The assesment of the basic tourist territorial resources: The case of the palyas of the north of the Comunidad Valenciana]. Investig. Geogr. 2003, 32, 111-135.

67. Medina, A.C.; Jiménez, F.B.G. Propuesta Metodológica Con SIG Para La Evaluación de La Potencialidad Del Territorio Respecto a Actividades Ecoturísticas y de Turismo Activo: Aplicación En La Sierra de Las Nieves (Málaga, España). [Methodological Proposal with GIS for the Evaluation of the Potential of the Territory in Ecotourism and Active Tourism Activities: Application in the Sierra de Las Nieves (Málaga, Spain)]. Rev. Investig. Turísticas 2011, 1. [CrossRef]

68. Pérez, Ó.R.; Crispín, Á.S. Metodología Para Determinar El Potencial de Los Recursos Turísticos Naturales En El Estado de Oaxaca, México. [Methodology to Determine the Potential of Natural Tourist Resources in the State of Oaxaca]. Cuad. Tur. 2005, 16, 153-174.

69. González-Ramiro, A.; Gonçalves, G.; Sánchez-Ríos, A.; Jeong, J. Using a VGI and GIS-based multicriteria approach for assessing the potential of rural tourism in Extremadura (Spain). Sustainability 2016, 8, 1144. [CrossRef]

70. Martin, S.A.; Assenov, I. Towards a surf resource sustainability index: A global model for surf site conservation and Thailand case study. In Proceedings of the 18th Asia Pacific Tourism Association Annual Conference (APTA) Hospitality E Tourism Education; New Tourism \& New Waves: Taipei, Taiwan; School of International Tourism, Dong-A University: Taipei, Taiwan; Busan, Korea, 2012; pp. 745-760.

71. Department of Cooperative Governance and Traditional Affairs-Republic of South Africa. City of Cape Town-Profile and Analysis-District Development Model. Cape Town. 2020. Available online: https://www.cogta.gov.za/ddm/wp-content/ uploads/2020/11/City-of-CT-September-2020.pdf (accessed on 13 June 2021).

72. Miraftab, F. Governing post apartheid spatiality: Implementing city improvement districts in Cape Town. Antipode 2007, 39, 602-626. [CrossRef]

73. Levenson, Z. Living on the fringe in post-apartheid Cape Town. Contexts 2017, 16, 24-29. [CrossRef]

74. Samara, T.R. Cape Town after Apartheid: Crime and Governance in the Divided City; University of Minnesota Press: Minneapolis, MN, USA, 2014; ISBN 978-0-8166-7000-0.

75. Frith, A. Dot Map of South Africa. Available online: https: / dotmap.adrianfrith.com/ ?lat=-34.0152\&lon=18.6411\&zoom=5.25 (accessed on 18 November 2020).

76. Wilkinson, P. City profile: Cape Town. Cities 2000, 17, 195-205. [CrossRef]

77. Nelson, G.; Polito, A. Information on currents in the Cape Peninsula Area, South Africa. S. Afr. J. Mar. Sci. 1987, 5, 287-304. [CrossRef]

78. Colenbrander, D.; Cartwright, A.; Taylor, A. Drawing a line in the sand: Managing coastal risks in the city of Cape Town. S. Afr. Geogr. J. 2015, 97, 1-17. [CrossRef]

79. Thompson, G. Surfing, Gender and Politics: Identity and Society in the History of South African Surfing Culture in the Twentieth Century. Ph.D. Thesis, Stellenbosch University, Stellenbosch, South Africa, 2015.

80. Wannasurf.com. Available online: https:/ / en.wannasurf.com/ (accessed on 28 November 2020).

81. Pike, S. Surfing South Africa; Double Storey: Cape Town, South Africa, 2007; ISBN 978-1-77013-114-9. 
82. Frey, N.; George, R. Responsible tourism management: The missing link between business owners' attitudes and behaviour in the Cape Town tourism industry. Tour. Manag. 2010, 31, 621-628. [CrossRef]

83. Rogerson, C.M.; Visser, G. African tourism geographies: Existing paths and new directions. Tijdschr. Voor Econ. Soc. Geogr. 2011, 102, 251-259. [CrossRef]

84. Swart, K.; Bob, U. The seductive discourse of development: The Cape Town 2004 olympic bid. Third World Q. 2004, 25, 1311-1324 [CrossRef]

85. WESGRO. Cape Town Regional Trends-January/ December 2019. Cape Town. 2020. Available online: https:/ /www.wesgro.co. za/uploads/files/Research/Cape-Town-Visitor-Trends-Annual-2019.pdf (accessed on 16 June 2021).

86. Pirie, G. Urban tourism in Cape Town. In Urban Tourism in the Developing World: The South African Experience; Rogerson, C.M., Visser, G., Eds.; Transaction Publishers: Piscatawa, NJ, USA, 2007; pp. 223-244; ISBN 978-0-7658-0358-0.

87. Kruger, M.; Myburgh, E.; Saayman, M. A Motivation-based typology of road cyclists in the Cape Town Cycle Tour, South Africa. J. Travel Tour. Mark. 2016, 33, 380-403. [CrossRef]

88. Spencer, J.P.; Uys, C. Accommodation, participants, sport-tourism, tourism, two oceans marathon. Afr. J. Hosp. Tour. Leis. 2015, 4, 1-16.

89. Steyn, J.N.; Spencer, J.P.; Martín-Gonzalez, R.; Swart, K. The ABSA cape epic mountain bike challenge: Impacts and legacies. Afr. J. Phys. Act. Health. Sci. 2016, 22, 315-334.

90. Ntloko, N.; Swart, K. Sport tourism event impacts on the host community: A case study of red bull big wave Africa. S. Afr. J. Res. Sport Phys. Educ. Recreat. 2008, 30, 70-93. [CrossRef]

91. Cape Town Municipal Government. Available online: https://webcache.googleusercontent.com/search?q=cache:RxHPsa8GVYcJ: https: / / www.capetown.gov.za/Family\%2520and\%2520home/See-all-city-facilities/Our-recreational-facilities/Beaches\&hl= es\&gl $=$ es\&strip $=1 \& v w s r c=0$ (accessed on 14 July 2020).

92. City of Cape Town. Know your Coast 2020. Cape Town. Available online: https://resource.capetown.gov.za/documentcentre/ Documents/City\%20research\%20reports\%20and\%20review/Know_Your_Coast_2020.pdf (accessed on 14 June 2021).

93. Windguru. Available online: https:/ / www.windguru.cz/91 (accessed on 28 November 2020).

94. Windfinder. Available online: https://windfinder.com/ (accessed on 28 November 2020).

95. Magic Sea Weed. Available online: https:/ / magicseaweed.com/ (accessed on 28 November 2020).

96. Surf-forecast.com. Available online: http:/ / es.surf-forecast.com/ (accessed on 28 November 2020).

97. Surfline.com. Available online: https:/ / www.surfline.com/ (accessed on 28 November 2020).

98. Wavescape-Surfing in South Africa. Available online: https:/ /www.wavescape.co.za/ (accessed on 28 November 2020).

99. Barbieri, C.; Sotomayor, S. Surf travel behavior and destination preferences: An application of the serious leisure inventory and measure. Tour. Manag. 2013, 35, 111-121. [CrossRef]

100. Espejo, A.; Losada, I.J.; Méndez, F.J. Surfing Wave Climate Variability. Glob. Planet. Chang. 2014, 121, 19-25. [CrossRef] 